\title{
Top 10 video game cases (US): how video game litigation in the US has evolved since the advent of Pong
}

\author{
Ross Dannenberg and Josh Davenport
}

\begin{abstract}
Video game litigation in the United States is neither new nor infrequent, and video game developers can learn valuable lessons from cases won, and lost, by others before them. This article examines the evolution of United States intellectual property law from historically narrow roots to classifying video games as an art form deserving broad free speech protection. This article examines seminal cases in a variety of IP areas, including not only copyrights, but also reverse engineering, derivative works, patents, trademarks, rights of publicity, the Digital Millennium Copyright Act, contracts, and freedom of speech. These cases explore the factual and legal limits of American jurisprudence in video game law, including how one's own expression can be limited by the rights of others, permissible and fair use and of others' IP, and the impact these cases have had in the industry. As video games have leveled up into a multi-billion dollar industry, the law has leveled up, too, and this article is the primer you need to level up with it.
\end{abstract}

Keywords: video games, intellectual property, patent, copyright, trademark, lawsuits

As video games have leveled up and become more sophisticated, the law has leveled up with them. Initially a fledgling industry operating out of inventors' garages, video games are now a multi-billion dollar industry with exceptionally valuable intellectual property. Increased popularity has resulted in their acceptance as a legitimate art form, leading to a transition for legal protection of video games from mere functional aspects to broader protection as a creative form of expression. Video game lawsuits over the past 40 years have followed this trend, and in this article we explore some of the most important video game cases in the United States as video games have undergone this evolution from mere machine to a form of art.

\section{Pong: where it all began}

The first major video game case, Magnavox Co. v. Activision, Inc. ${ }^{1}$ was a patent infringement lawsuit that

\footnotetext{
Ross Dannenberg is a senior partner with the intellectual property law firm Banner \& Witcoff in Washington, D.C. Ross is the editor-in-chief of the video game IP blog PatentArcade.com, the editor and an author of the American Bar Association's Legal Guide to Video Game Development (2nd ed., 2016), and is an editor of Computer Games and Immersive Entertainment: The Next Frontiers in Intellectual Property Law (2nd ed., Fall, 2018). Josh Davenport is also an attorney with Banner \& Witcoff in Washington, D.C., was recognized by Managing Intellectual Property as among the top 50 most active attorneys for inter partes review petitions in 2017, and has a broad patent practice leveraging his experience as a former telecom engineer. The authors wish to thank Andrew Thomas, a $3 \mathrm{~L}$ at
}

hinged on purely functional aspects. Magnavox's Odyssey game console, the inspiration for Pong and synonymous with early video games, featured two players who bounced a simple white dot back-and-forth across the screen in a form of virtual ping-pong. Magnavox pursued broad patent protection over its gaming devices, with one claim of the asserted patent reciting:

\begin{abstract}
51. Apparatus for generating symbols upon the screen of a television receiver to be manipulated by at least one participant, comprising: means for generating a hitting symbol; and means for generating a hit symbol including means for ascertaining coincidence between said hitting symbol and said hit symbol and means for imparting a distinct motion to said hit symbol upon coincidence. ${ }^{2}$
\end{abstract}

In the 1980s Activision produced games for the Atari 2600, Commodore 64, and PC. Its games included Tennis, Ice Hockey, and Grand Prix games (among others) that generally followed the 'ball and paddle' format described by Magnavox's patent. ${ }^{3}$ The litigation focused on technical

American University, Washington College of Law, in Washington, D.C., for his assistance with legal research during the preparation of this article.

1 No. C-82-5270-CAL, 1985 WL 9496 (N.D. Cal. December 27, 1985), aff d, 848 F.2d 1244 (Fed. Cir. 1988).

2 U.S. Reissue Patent No. RE28, 507 col. 31, 1. 57-65 (filed April 25, 1974) (available at https://patents.google.com/patent/USRE28507).

3 Magnavox Co. v. Activision, Inc., No. C-82-5270-CAL, 1985 WL 9496, at ${ }^{\star} 12$ (N.D. Cal. December 27, 1985), Aff d The Magnavox Company and Sanders Associates, Inc. v. Activision, Inc., 848 F.2d 1244 (Fed. Cir. 1988). 


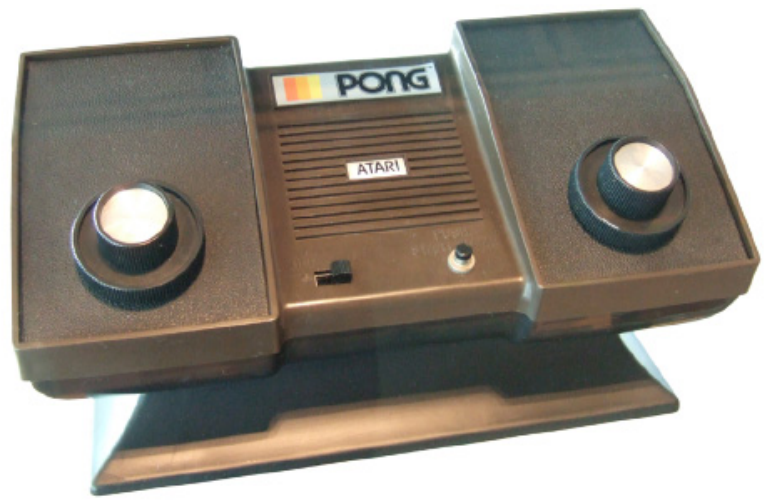

Figure 1 Pong, the subject of Magnavox v. Activision - The Progenitor of Video Game Cases

aspects of the Magnavox Odyssey and Activision's games, including a contention by Activision that the claim elements were recited in so-called means-plus-function format, which requires that a claim be interpreted based on the physical hardware (means) described in the patent to perform the claimed functions. Activision argued that the claims should be narrowly construed to the described circuitry, including 'slicer circuits' and making use of 'sawtooth waveforms'. ${ }^{4}$ Video game technology had advanced considerably in the ten years following the release of Pong, and the dedicated electrical circuitry that made up the original game had been replaced by 'basically digital circuitry including a microprocessor'. ${ }^{5}$ Thus, if Activision could limit the claims through a strict means-plus-function interpretation, it might be able to escape infringement.

However, the court's holding foreshadowed the future of video game law, stating: 'the use of currently available technology to implement television games does not alter the basic nature of those games or avoid [Magnavox's] patent. ${ }^{36}$ While the parties were wrapped up in the technical details of the devices (which is understandable given the meansplus-function claims), the court took into account 'advances in technology' and saw Magnavox's patent as something beyond specific circuitry on a circuit board. ${ }^{7}$ The court's holding hinted that the court saw the 'basic nature of those games' as something more - that a video game patent is as much about protecting the resultant expression represented by the game as it is the cold, technical, functional aspects that make that expression a playable reality.

In the end, the court held Activision liable for patent infringement. Magnavox went on to enforce its patents

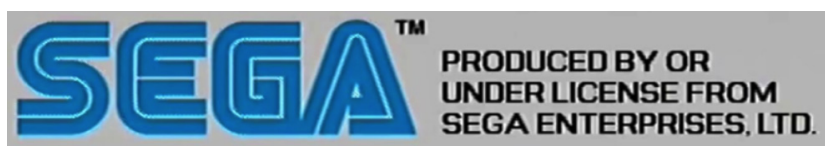

Figure 2 Sega Enterprises, Ltd. v. Accolade - Reverse Engineering is Permissible

against virtually every game publisher whose game used a ball and paddle format of any kind.

\section{Sega v. Accolade}

Increased competition in the early video game console market led to increasing attempts to add technical and legal protection for the valuable intellectual property in the games being sold globally. In the early 1990s, Nintendo and Sega were in a heated battle for the hearts and minds of America's children (hearts and minds that would indeed turn video games into a multi-billion dollar industry), and turned to a powerful tool in their attempt to control the industry - licensing. By requiring game developers to purchase a license to develop games for Nintendo's and Sega's respective game consoles, Nintendo and Sega could ensure that they maintained control over the products being released on their respective platforms (Super Nintendo and Sega Genesis). Licensing was an important tool both in terms of monetizing their platforms and in maintaining quality control to prevent the sort of shoddy game quality that had helped to doom the Atari 2600 console. In Sega's case, it attempted to enforce its licensing by requiring the use of a copyrighted initialization code that triggered the on-screen display of Sega's logo on the game console. ${ }^{8}$ Without a license, a game developer did not have access to the copyrighted code to unlock the game console.

Accolade attempted to circumvent this licensing requirement by reverse-engineering the initialization code required to run software on the Sega Genesis. ${ }^{9}$ Sega sued, claiming that by copying its object code in Accolade's games, Accolade was infringing Sega's copyrights. ${ }^{10}$ Reviewing an emergency appeal of a preliminary injunction against Accolade instituted by the district court, the Ninth Circuit Court of Appeals agreed with Sega that the code was copied, and even agreed with Sega that the majority of Accolade's defenses were without merit. ${ }^{11}$ However, the Ninth Circuit ultimately held that Accolade did not infringe under the doctrine of fair use for a variety

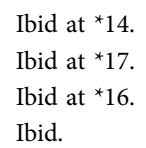

8 Sega Enterprises Ltd. v. Accolade, Inc., 977 F.2d 1510, 1514 (9th Cir. 1992), as amended (January 6, 1993).

9 Ibid at 1522

10 Ibid at 1517-19.

11 Ibid at 1518. 
of reasons. ${ }^{12}$ First, the court noted the difficulty in punishing Accolade for making use of a code that was clearly designed to serve a functional purpose, stating that:

Taken together, these facts indicate that although Accolade's ultimate purpose was the release of Genesis-compatible games for sale, its direct purpose in copying Sega's code, and thus its direct use of the copyrighted material, was simply to study the functional requirements for Genesis compatibility so that it could modify existing games and make them usable with the Genesis console. Moreover, as we discuss below, no other method of studying those requirements was available to Accolade. On these facts, we conclude that Accolade copied Sega's code for a legitimate, essentially non-exploitative purpose, and that the commercial aspect of its use can best be described as of minimal significance. ${ }^{13}$

Of particular interest is the court's statement that the commercial aspect of Accolade's use had 'minimal significance'. Clearly, the ability to produce games on a console without licensing was commercially important. However, the court's ruling makes clear that the commercial significance is minimized in view of the fact that only the functional, and therefore non-copyrightable, aspects of the code were ultimately what was used in Accolade's end product. Essentially, Accolade only cared about the functional aspects, which are not protected by copyright, and thus its use was fair use under US law.

Second, the court stated that allowing the code to be copied furthered the goals of the Copyright Act, because 'Accolade's identification of the functional requirements for Genesis compatibility has led to an increase in the number of independently designed video game programs offered for use with the Genesis console'. ${ }^{14}$ By divesting non-protected functional aspects from creative aspects, the court found that public policy favored copying Sega's copyrighted expression in this case. ${ }^{15}$ Thus, even though the court denied protection under the copyright statute, it did so because it saw the value that promoting video game development had for the public. In the end, the court used the doctrine of fair use to avoid what today might be characterized as copyright misuse, namely, the use of a copyright to protect more than that which is protectable under copyright law.

It's an open question whether one could avail oneself of the Digital Millennium Copyright Act (DMCA, enacted October 12, 1998) to prevent this sort of copying where the functional aspects (as well as the non-functional aspects) of software are protected behind a technological

Ibid at $1527-28$.

13 Ibid at 1522-23.

14 Ibid at 1523

15 Ibid at 1520 ('Where there is good reason for studying or examining the unprotected aspects of a copyrighted computer program, disassembly for purposes of such study or examination constitutes a fair use').

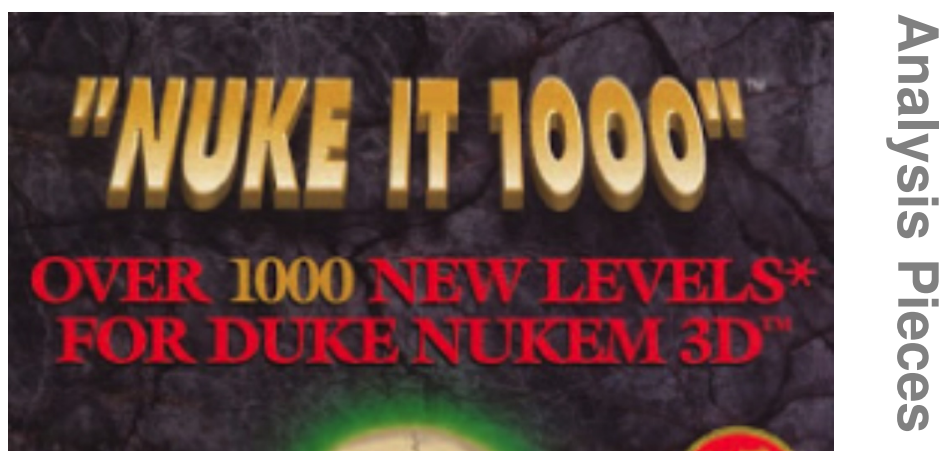

measure that effectively controls access to the software as a whole. ${ }^{16}$ At least one court has held that copyright holders must consider fair use in good faith before issuing take down notices under the DMCA. ${ }^{17}$ However, whether other courts follow that lead, or even apply the ruling to other aspects of the DMCA, remains to be seen.

\section{Micro Star v. FormGen: Duke Nukes 'Em}

In Micro Star v. FormGen ${ }^{18}$ the district court and appellate court struggled with the technical implementation of a game in reaching contrary conclusions. FormGen, Inc. made and distributed the incredibly popular shooter Duke Nukem $3 D .{ }^{19}$ While the game included its own story with twenty-nine levels, the game also included a level editor that gave players the ability to create their own levels (which could be shared freely over the Internet). ${ }^{20}$ Micro Star collected three hundred popular levels and began selling them as a collection on CD called
1617 U.S.C. $\$ 1201$.

17 Lenz v. Universal Music Group, 801 F.3d 1126 (9th Cir. 2015).

8154 F.3d 1107 (9th Cir. 1998).

19 Ibid at 1109.

20 Ibid. 
Nuke It. FormGen requested that Micro Star cease such practices, prompting Micro Star to file a lawsuit for declaratory judgment that it did not infringe FormGen's copyrights. As the Ninth Circuit Court of Appeals put it, 'Duke Nukem routinely vanquishes Octabrain and the Protozoid Slimer. But what about the dreaded Micro Star?'21

The appellate court's decision again hinged on placing the proper emphasis on the creative aspects of a video game rather than the functional. The district court had originally focused on whether the literal elements of Duke Nukem 3D were reproduced as part of Micro Star's collection. ${ }^{22}$ Because the levels themselves consisted of MAP files that merely pointed to material already present in the Duke Nukem $3 D$ game (e.g., the MAP file referred to an enemy, but relied on the base game to provide the depiction of the enemy on screen in response to the MAP file), the court held that the audiovisual elements originated from the base Duke Nukem $3 D$ game and not the Nuke It collection. ${ }^{23}$ In the district court's mind, the MAP files were nothing more than architectural drawings, instructing the game engine itself how to render a new Duke Nukem 3D level merely according to the MAP file's schematics, and it was during that rendering process that artwork and other creative aspects of the Duke Nukem $3 D$ universe were actually used. Thus, the district court held that infringement was limited only to screenshots of the game used, for example, as part of the collection's commercial packaging for store shelves.

The Ninth Circuit disagreed with this approach, comparing the MAP files to 'a paint-by-numbers kit'. ${ }^{24}$ The court held that, while MAP files may not directly reproduce copyrighted audiovisual products, '[w]hat, after all, does sheet music do but describe in precise detail the way a copyrighted melody sounds?'25 As such, the court held that 'the audiovisual displays assume a concrete or permanent form in the MAP files' despite not containing the audiovisual material itself. ${ }^{26}$ The court held that the game was more than just images and videos. Rather, the MAP files infringed on protected creative expression because they reproduced 'a beefy commando type named Duke who wanders around post-Apocalypse Los Angeles, shooting Pig Cops with a gun, lobbing hand grenades, searching for medkits and steroids, using a jetpack to leap over obstacles, blowing up gas tanks, avoiding radioactive slime'. ${ }^{27}$

There is a good argument that this case was decided wrongly, but this case has never been explicitly overturned. Specifically, any video game could be programmed to use the MAP files to generate a level using the artwork, sounds, textures, skins, and creative expression of that game. The MAP files do not themselves dictate that the Duke Nukem $3 D$ engine be used for rendering. Imagine, if you would, that a MAP file distributed by Micro Star was used to generate a level in Quake, Doom, or Unreal. Would that rendering be an infringement of FormGen's IP in Duke Nukem 3D? No. ${ }^{28}$ Of note in this case is that Duke Nukem $3 D$ was the only game at the time that was actually capable of reading MAP files and rendering corresponding levels, and Micro Star was doing something wrong, even if not directly infringing FormGen's IP. But if Micro Star wasn't infringing FormGen's IP, then whose? In actuality, Micro Star was likely infringing the copyright rights of the users who created the levels distributed for free online that Micro Star was repackaging and reselling. However, the license agreement distributed with Duke Nukem $3 D$ limited user's rights in those levels requiring, among other things, that the MAP files not be sold. ${ }^{29}$ Micro Star wasn't a party to that agreement with respect to those levels, and thus believed itself to be free to repackage and sell MAP files created by others without recourse from FormGen. ${ }^{30}$ Because, in the Ninth Circuit's mind, Micro Star was unfairly benefiting from someone else's work, and because FormGen was as appropriate a rights holder as the court would likely get under these circumstances, the court held Micro Star liable for copyright infringement. ${ }^{31}$ While perhaps a 'just' result, it doesn't negate that bad facts make bad law. Perhaps this case will be revisited in the future, in view of the myriad of cases that have held that a link to an infringing web site is not itself copyright infringement, just like the MAP files merely describe how to
21 Ibid.

22 Microstar v. Formgen, Inc., 942 F.Supp. 1312, 1316 (S.D. Cal. 1996), aff d in part, rev'd in part sub nom. Micro Star v. Formgen Inc., 154 F.3d 1107 (9th Cir. 1998).

23 Microstar, 942 F.Supp. at 1316; see also Williams Elecs., Inc. v. Artic Int'l, Inc., 685 F.2d 870 (3rd Cir. 1982) (audiovisual elements of a game meet fixation requirement of copyright law).

24 Micro Star, 154 F.3d at 1110

25 Ibid at 1112.

26 Ibid; cf. Lewis Galoob Toys, Inc. v. Nintendo of Am., Inc., 964 F.2d 965 (9th Cir. 1992), as amended (August 5, 1992).
27 Micro Star v. Formgen Inc., 154 F.3d 1107, 1112 (9th Cir. 1998). Cf. Scott M. Kelly and Kirk A. Sigmon, 'The key to key presses: eSport game input streaming and copyright protection', 1 Interactive Entm't L. Rev. 2 (2018) (discussing if input streams are copyrightable insofar as they merely describe how to interact with a video game, and contain no video game content themselves).

29 Micro Star, 154 F.3d at 1113

30 Ibid.

31 Ibid. 


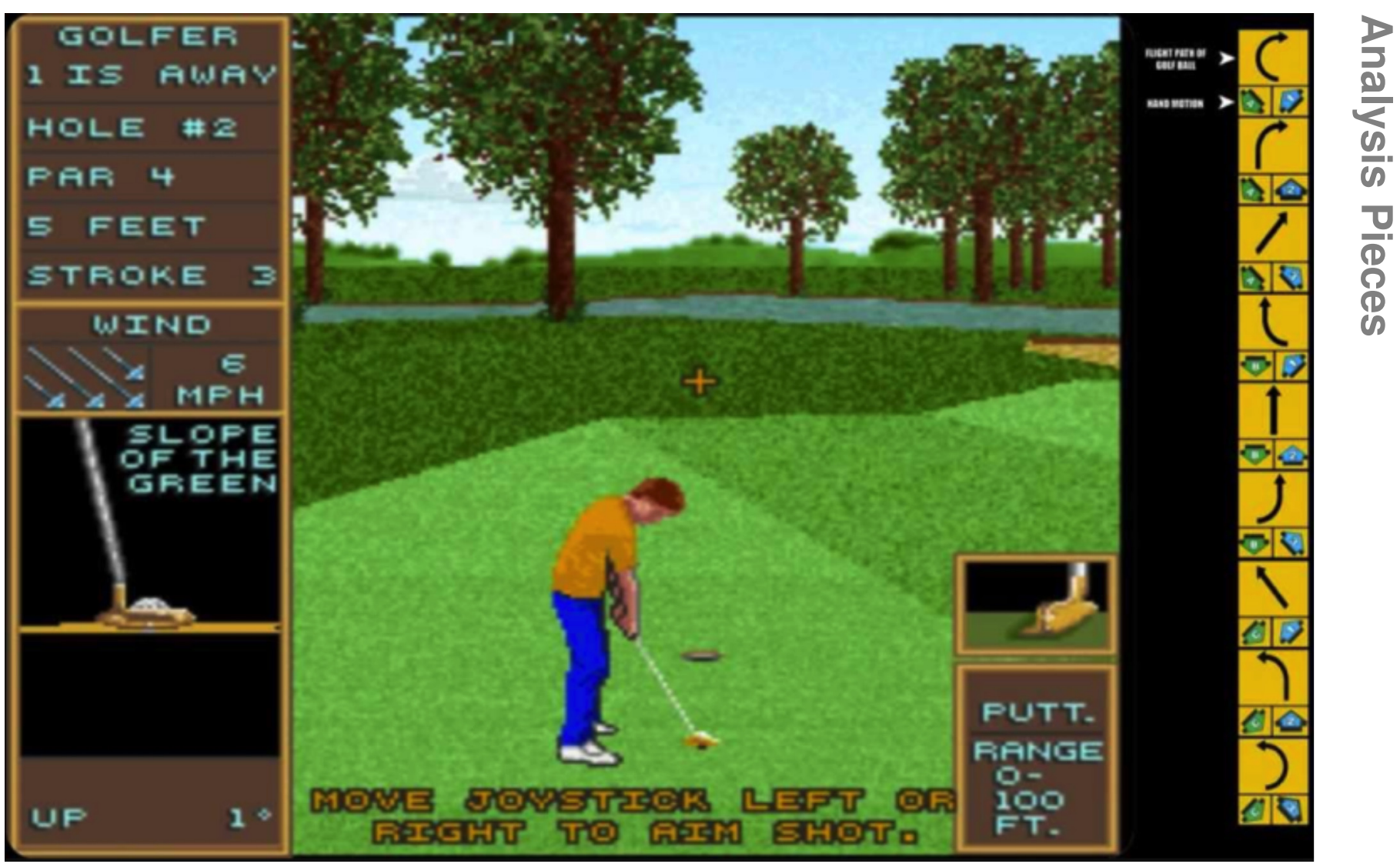

Figure 4 Incredible Technologies v. Virtual Technologies - A Swing and a (Functional) Miss

construct a new game level (more akin to architecture) without incorporating any of the infringing content itself. $^{32}$

\section{Fore! Incredible Technologies v. Virtual Technologies}

While the Micro Star case illustrates the potential strength of video game copyrights, Incredible Technologies learned the hard way that copyrights indeed have limits, and that overreliance on creative aspects of a game, especially when innovative aspects are more functional, may prove fatal. Incredible Technologies produced Golden Tee, a golf arcade game catering heavily to pool halls, bars, and restaurants with over forty thousand gaming cabinets sold. ${ }^{33}$ The key feature of the game is the use of a trackball as a controller, wherein the player swings a golf club by rolling the trackball

32 See, e.g., Perfect 10, Inc. v. Google, Inc., 508 F.3d 1146, 1160-62 (9th Cir. 2007) (holding that Google's HTML links did not infringe a copyright owner's distribution right because the links merely instructed a user's browser to the image source); see also Grady v. Iacullo, No. 13-cv00624-RM-KMT, 2016 WL 1559134, at *4-8 (D. Colo. April 18, 2016). backwards and then forwards. ${ }^{34}$ Aware of the game's popularity, Virtual Technologies obtained a Golden Tee game and delivered it to NuvoStudios with instructions to create a new version of the game, PGA Tour Golf, which used the same trackball swing mechanic as Golden Tee. ${ }^{35}$ The end result was that if a player already knew how to swing a golf club in Golden Tee, that same player could learn to play PGA Tour Golf with only a minimal learning curve, if any at all.

The Seventh Circuit Court of Appeals, reviewing a denial of a temporary restraining order by the district court, declined finding copyright infringement, because the truly 'creative' aspects were functional - the use of a trackball as a controller - and the remaining creative aspects fell under the scènes à faire doctrine. ${ }^{36}$ The Copyright Act does not extend protection to scènes à faire, namely, 'incidents, characters or settings which are as a practical matter indispensable, or at least
33 Incredible Techs., Inc. v. Virtual Techs., Inc., 400 F.3d 1007, 1009 (7th Cir. 2005).

34 Ibid at 1010

35 Ibid.

36 Ibid at 1011-12 


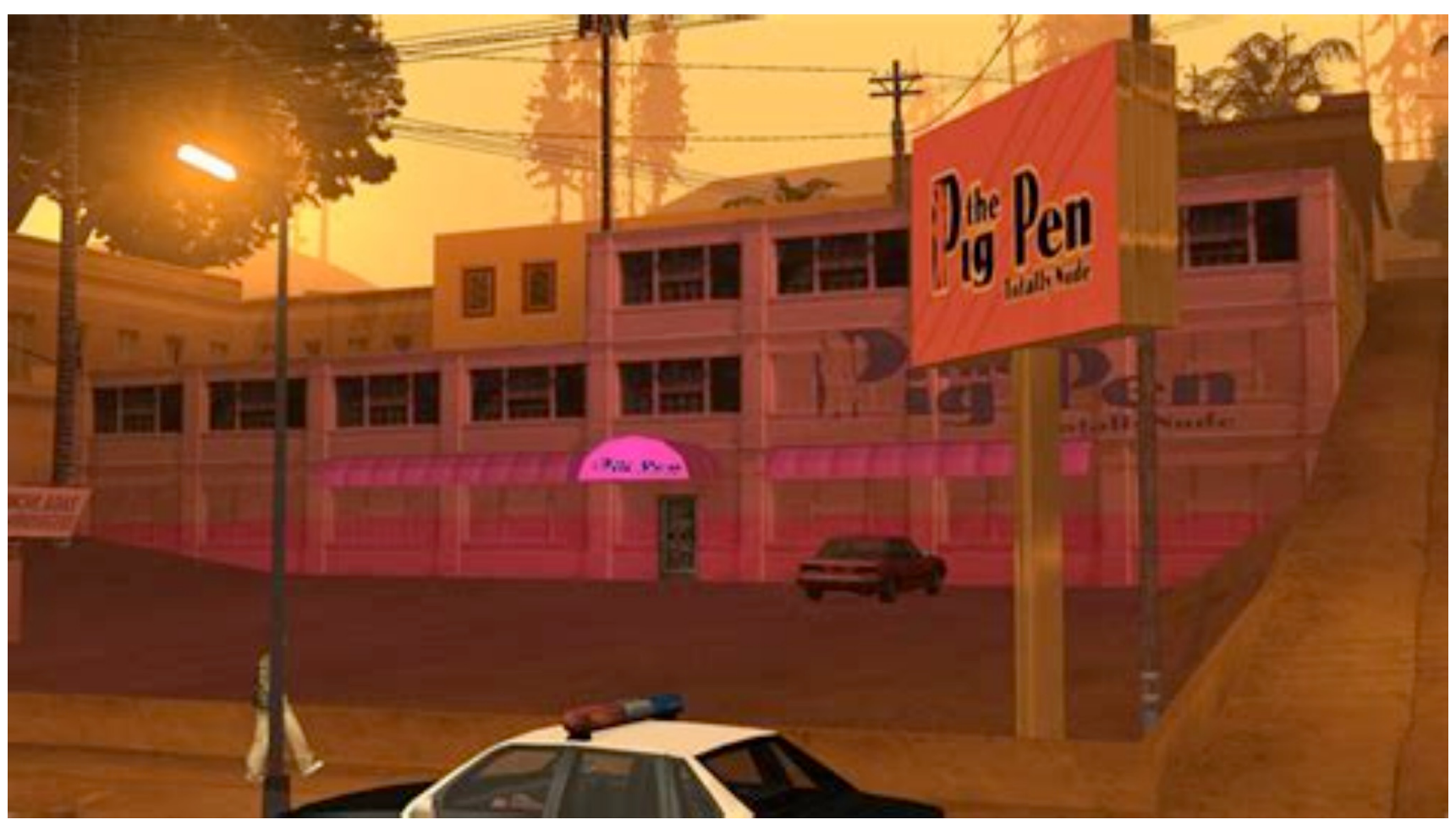

Figure 5 ESS Entertainment 2000 v. Rock Star - No Grand Theft Trademark

standard, in the treatment of a given topic'. ${ }^{37}$ Thus, the trappings of a golf game - golf courses, players, clubs, balls, and even beautiful weather, all fall outside the scope of protected content. Further, the court opined that 'the elements of our two games, which are most significant and most clearly similar, are not before us. The trackball system of operating the game is not subject to copyright protection'. ${ }^{38}$ Rather, functional features are generally within the domain of the patent laws. ${ }^{39}$ The court noted that this exclusion 'grows out of the tension between copyright and patent laws' and that '[f] unctional features, such as the trackball system, might, at least potentially might, be eligible for patent protection'. ${ }^{40}$

Had Incredible Technologies obtained a patent on its innovative game mechanic using a trackball for a golf game, it likely could have obtained a favorable

37 Ibid (quoting Atari, Inc. v. North American Philips Consumer Elecs. Corp., 672 F.2d 607, 616 (7th Cir. 1982)).

38 Incredible Techs, 400 F.3d at 1012

39 See 17 U.S.C. $\$ 102$ (b) ('In no case does copyright protection from an original work of authorship extend to any idea, procedure, process, system, method of operation, concept, principle, or discovery, regardless of the form in which it is described, explained, illustrated, or embodied in such work.'); see also Baker v. Selden 101 U.S. 99, 102 (1879) ('To give to the author of the book an exclusive property in the art described therein

[t] hat is the province of letter-patent, not of copyright'); Am. Dental Ass'n v. Delta Dental Plans Ass'n, 126 F.3d 977, 980 (7th Cir. 1997) ('A lamp may be entirely original, but if the novel elements are also functional the lamp cannot be copyrighted. This is not a line between intellectual judgment-a judgment that may have included treble damages given the evidence of intentional copying in this case. ${ }^{41}$ However, Incredible Technologies chose to rely on creative aspects of its game protected under copyright. Thus, while trends may indicate that creative aspects of a game are increasingly suitable for protection, a client who foregoes pursuing patent protection for functional aspects of its games does so at its own peril.

\section{Party like a rock star: E.S.S. v. Rock Star Videos}

Rock Star games is the developer of the wildly popular Grand Theft Auto video game series. ${ }^{42}$ Grand Theft Auto: San Andreas plays on West Coast 'gangster' culture, and features the city of 'Los Santos' that is heavily

property and the public domain; it is a line among the bodies of intellectual-property law').

40 Incredible Techs., Inc. v. Virtual Techs., Inc., 400 F.3d 1007, 1012 (7th Cir 2005) (citing Am. Dental Ass'n, 126 F.3d at 980).

4135 U.S.C. $\$ 284$. A successful plaintiff in patent cases is statutorily entitled to 'up to three times the amount [of damages] found or assessed' when willful infringement is found.

42 The most recent version, Grand Theft Auto $V$, generated US\$800 million in revenue in just 24 hours following release. Andrew Goldfarb, GTA 5 makes $\$ 800$ Million in one day, IGN (September 18, 2013, 12:02 PM PDT), http://www.ign.com/articles/2013/09/18/gta-5-makes-800-millionin-one-day. 
based on real-life Los Angeles and its various neighborhoods. ${ }^{43}$ E.S.S. operates a strip club in downtown Los Angeles called the Play Pen Gentleman's Club, with the words 'the Play Pen' and 'Totally Nude' in a publicfacing sign, and featuring a nude female dancer in the stem of the first ' $\mathrm{P}$ '. ${ }^{44}$ Rock Star, drawing inspiration from the club, included its own strip club in San Andreas called the 'Pig Pen' with a sign that was similar but without, for example, the 'Totally Nude' signage. ${ }^{45}$ The purveyors of the Play Pen, seemingly insulted that their upstanding establishment was mocked in San Andreas, sued Rock Star for trademark infringement.

However, the Ninth Circuit was not persuaded, noting that any trademark claim presupposes use of a similar mark - but that is only the start of the analysis. ${ }^{46}$ The court applied the Rogers $v$. Grimaldi test, ${ }^{47}$ balancing 'Rockstar's artistic goal, which is to develop a cartoonstyle parody of East Los Angeles' with 'whether the Game would confuse its players into thinking that the Play Pen is somehow behind the Pig Pen or that it sponsors Rockstar's product'. ${ }^{48}$ The Rogers test is a twopronged test that holds that an artistic work's use of a trademark is not an infringement 'unless the [use of the mark] has no artistic relevance to the underlying work whatsoever, or, if it has some artistic relevance, unless [it] explicitly misleads as to the source or the content of the work'. ${ }^{49}$ Based on the Rogers test, the court found no such confusion exists, stating:

The San Andreas Game is not complementary to the Play Pen; video games and strip clubs do not go together like a horse and carriage or, perish the thought, love and marriage. Nothing indicates that the buying public would reasonably have believed that ESS produced the video game or, for that matter, that Rockstar operated a strip club. A player can enter the virtual strip club in Los Santos, but ESS has provided no evidence that the setting is anything but generic. It also seems farfetched that someone playing San Andreas would think ESS had provided whatever expertise, support, or unique stripclub knowledge it possesses to the production of the game. After all, the Game does not revolve around running or patronizing a strip club. Whatever one can do at the Pig Pen seems quite incidental to the overall story of the Game. A reasonable consumer would not think a company that owns one strip club in East Los Angeles, which is not well known to the public at large, also produces a technologically sophisticated video game like San Andreas. ${ }^{50}$ Cir. 2008).

44 Ibid at 1097

45 Ibid.

46 Ibid at 1099 ('After all, a trademark infringement claim presupposes a use of the mark').

47 Rogers v. Grimaldi, 875 F.2d 994, 999 (2nd Cir. 1989).
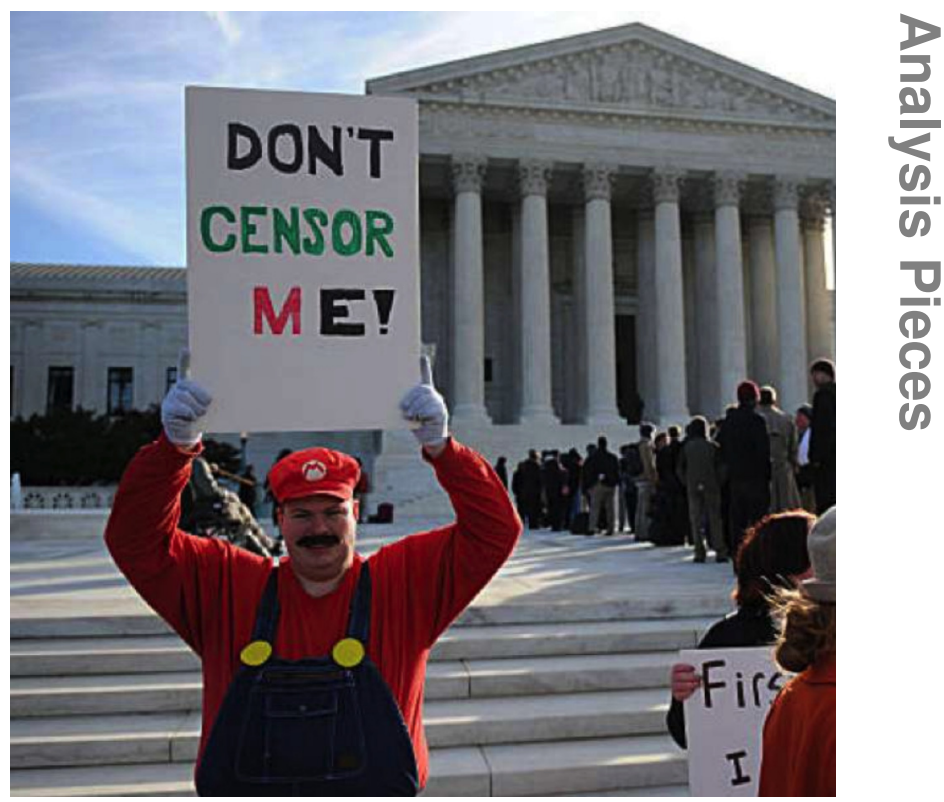

Figure 6 Brown v. Entertainment Merchants - Video Games Reign Supreme

In short, trademark protection is limited to confusion regarding the originator of a product, protection that is frequently only incidental to the intellectual property one wishes to protect. Thus, while trademark infringement may exist in many counterfeiting cases (where an infringer imitates the packaging or advertising of a legitimate producer of content), uses of a trademark within the confines of a video game world (or other creative expression) do not typically rise to the level of consumer confusion sufficient for infringement under trademark law as long as the use of the mark has artistic relevance to the video game and does not explicitly mislead as to the source or content of the video game. ${ }^{51}$

\section{Brown v. EMA: the Supremes weigh in}

Video games have had a tremendous impact on society since their invention, and with that growing significance has been an equally growing concern about their influence. One question, though, was what protections - if any - video games as a medium have from the United States Constitution under the rights of free speech, and

48 E.S.S. Entm't 2000, 547 F.3d 1095 at 1100

49 Rogers, 875 F.2d at 999.

50 E.S.S. Entm't 200, 547 F.3d 1095 at 1100-01.

51 See, e.g. Universal City Studios, Inc. v. Nintendo Co., 746 F.2d 112 (2nd Cir. 1984). 
whether they are to be treated as creative or functional works under U.S. Copyright law. These questions were finally answered by the United States Supreme Court in 2011 in Brown v. Entertainment Merchants Ass'n. ${ }^{52}$ In that case, the Court stated that' [1]ike the protected books, plays, and movies that preceded them, video games communicate ideas - and even social messages through many familiar literary devices (such as characters, dialogue, plot, and music) and through features distinctive to the medium (such as the player's interaction with the virtual world) ${ }^{53}$ The Court also made clear that "the most basic principles of freedom of speech ... do not vary" when a new and different medium for communication appears. ${ }^{54}$

So how did we finally get video games before the Supreme Court? In that case, California passed a bill that prohibited the sale or rental of 'violent video games' to minors, and required the game packaging to have a label indicating the minimum appropriate age as ' 18 '. ${ }^{55}$ The law defined 'violent video games' as those 'in which the range of options available to a player includes killing, maiming, dismembering, or sexually assaulting an image of a human being, if those acts are depicted' in a manner that ' $\mathrm{a}$ ] reasonable person, considering the game as a whole, would find appeals to a deviant or morbid interest of minors', that is 'patently offensive to prevailing standards in the community as to what is suitable for minors', and that 'causes the game, as a whole, to lack serious literary, artistic, political, or scientific value for minors. ${ }^{56}$ Even though California attempted to 'make [its] violentspeech regulation look like obscenity regulation', ${ }^{57}$ and thereby attempting to place the regulation under the purview of obscenity regulations of obscene depictions of sexual conduct, the Court expressly rejected any analogy. Specifically, the Court concisely held that 'speech about violence is not obscene. ${ }^{58}$

Beyond the Constitutional implications about violence as protected speech, especially as it is directed towards minors, Brown has the distinction of making clear that video games are genuine, protectable speech. ${ }^{59}$ The Court rejected the idea that video games were a 'special problem' because of their interactive nature, and instead likened them to any

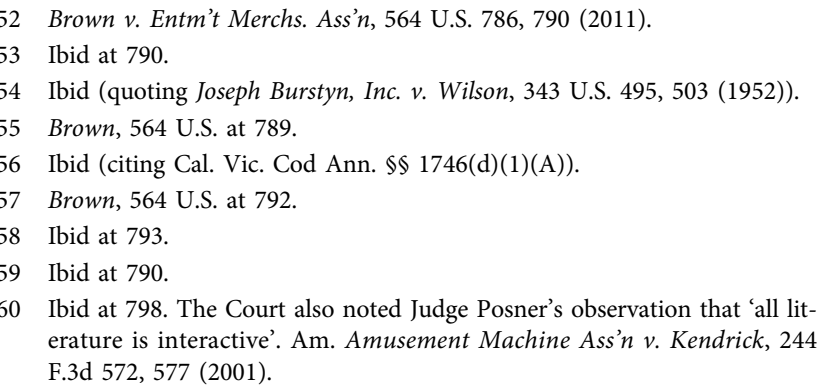

other type of entertainment that communicates ideas and social messages using features distinctive to a medium, such as choose-your-own-adventure stories. ${ }^{60}$ Said otherwise, the Court held that video games are an expression that is more than the tangible medium through which the video game is manifested. Thus, California did not have 'free-floating power to restrict the ideas to which children may be exposed', even when those ideas were manifested in the form of a video game. ${ }^{61}$ This ruling may have differed if there was 'a longstanding tradition in this country of specially restricting children's access to depictions of violence, but there is none'. ${ }^{62}$

The strength of the First Amendment protections afforded to video games is evident in the Court's use of the strict scrutiny standard, the most rigorous standard of judicial review in the United States. ${ }^{63}$ The Court held that California was only able to document 'at best some correlation' between video games and children's increased feelings of aggression, and there was no evidence that the effects of video games were any greater than those experienced from Saturday morning cartoons. ${ }^{64}$ Because California decided to single out video games over other media, without any persuasive reason, the California law was held to be unconstitutional.

The effect of Brown v. Entertainment Merchants Ass'n should not be underestimated. While it might be easy to dismiss Brown as a case about obscenity, it is so much more. Brown validated video games as an art form, placing video game creators on par with novelists, script writers, and directors. The highest court in our land has affirmatively stated that video games are deserving of the same level of protection as books, plays and movies. No longer are video game developers the step-children of the creative arts.

\section{Tetris: the most popular game ever gets its day in court}

Early video game case law established that copyright does not extend to 'standard game devices' ${ }^{65}$ Rather, protection was more likely to be granted only to video game characters. ${ }^{66}$ However, as games have transitioned

61 Ibid at 794 .

62 Ibid at 795 .

63 Ibid at 799. In order to pass this standard, the government must demonstrate a compelling governmental interest, and that the law was narrowly tailored to serve that interest.

64 Ibid at 800-02.

65 Atari, Inc. v. N. Am. Philips Consumer Elecs. Corp., 672 F.2d 607 (7th Cir. 1982).

66 Ibid. 


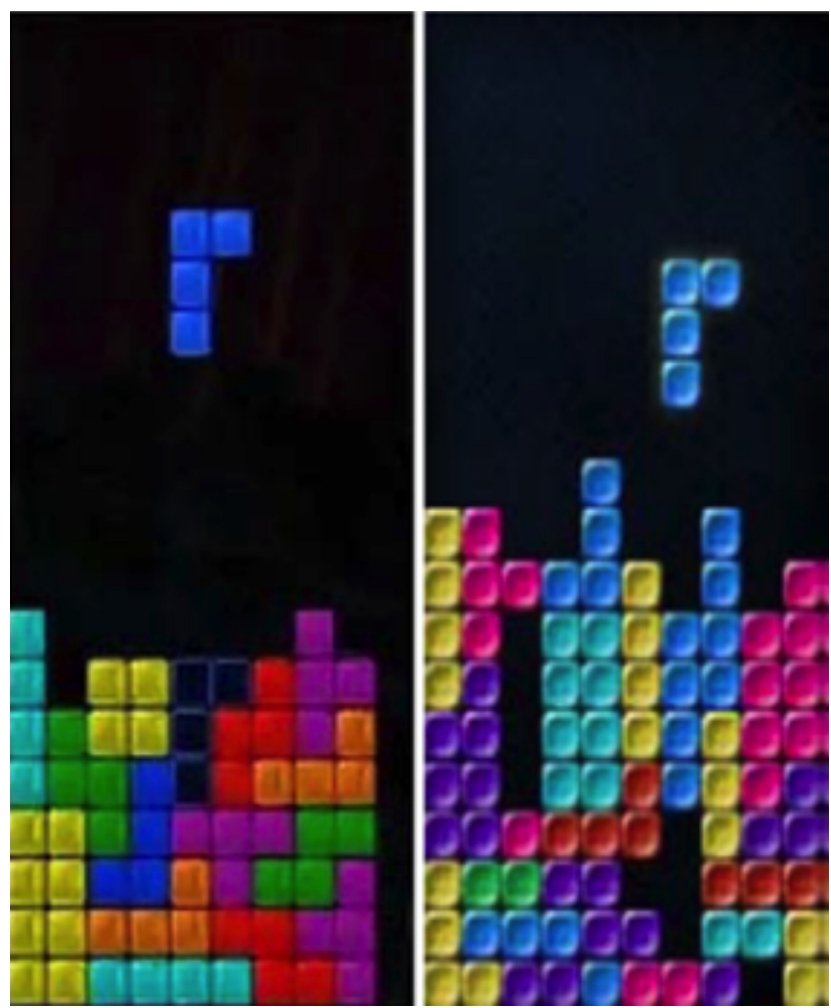

Figure 7 Tetris Holding v. Xio Interactive - Even a Bunch of Simple Pieces Can Be Expressive

from single-player interactions with dot-matrix or PacMan like levels to become more complex, interactive, and graphically realistic immersive entertainment experiences, and in view of 2011's Brown v. Entertainment Merchants Ass'n decision, courts have gradually strengthened the scope of video game copyrights. This trend towards video games as a creative medium deserving of strong copyright protection perhaps culminated with Tetris Holding v. Xio Interactive, ${ }^{67}$ which holds that even relatively simple games can have seemingly strong copyright protection. ${ }^{68}$

Since its launch in the 1980s, Tetris has expanded to a global scale and is now a cultural icon. ${ }^{69}$ Xio was inspired by Tetris to create a multiplayer game for mobile called Mino. Mino was admittedly a clone of Tetris, but Xio argued it copied only unprotectable functional aspects of Tetris, because the game's simplistic design necessitates certain choices. $^{70}$ Tetris argued that Mino infringed on its copyright by copying, virtually identically, most of Tetris. ${ }^{71}$ The court held there were still many protectable aspects, stating 'Tetris Holding is as entitled to copyright protection for the way in which it chooses to express game rules or game play as one would be to the way in which one chooses to express an idea' ${ }^{72}$

In coming to that conclusion, the court first compared the games side-by-side and determined that a layman would find them substantially similar. ${ }^{73}$ The court then dismissed the idea that tying design elements to a rule or function was sufficient to overcome an entity's copyright protections; instead, while Tetris 'has given the [functional] rules of its game to the public domain, [...] it has kept the rights to expression' ${ }^{74}$ It is easy to take for granted that Tetris's design 'is a wholly fanciful presentation'75 with many possible alternatives, so '[t]here was no necessity for Mino to mimic Tetris's expression other than to avoid the difficult task of developing its own take on a known idea' ${ }^{76}$

While some might argue that Tetris is wholly functional and should be free to clone, in the minds' of these authors this case illustrates the notion that functional aspects of a game, each of which might be unprotectable by itself, when taken together in combination result in a creative selection or arrangement of features that results in protectable expression of the game as a whole, not dissimilar to the result in Feist Publications, Inc. v. Rural Telephone Service Co. ${ }^{77}$ In Feist, the Supreme Court held that a compilation of facts might still be copyrightable if the manner in which the compiler has selected or arranged the facts is original. ${ }^{78}$ If the selection or arrangement is original, the particular combination of facts is eligible for copyright protection. ${ }^{79}$ If the selection and arrangement are unoriginal, as was the case with the alphabetically arranged white pages in Feist, the work is not protectable by copyright. ${ }^{80}$ While on its face Feist was limited to a compilation of facts, it is not a giant leap from facts to standard game devices. In the parlance of Feist, this would create a standard where standard game devices, whether alone or as part of a compilation, are still not original and therefore may not be copyrighted. But a compilation of standard
67863 F. Supp. 2d 394 (D.N.J. 2012)

68 Ibid at 396.

69 Ibid.

70 Ibid at 397.

71 Ibid at $397-98$

72 Ibid at 405.

73 Tetris Holding, LLC v. Xio Interactive, Inc., 863 F.Supp.2d 394, 409 (D.N.J 2012); see also Universal Athletic Sales Co. v. Salkeld, 511 F.2d 904, 908 (3rd Cir. 1975).

74 Tetris Holding, 863 F.Supp.2d at 411.
75 Ibid at 412 .

76 Ibid at 411; see also Spry Fox LLC v. LOLApps Inc., No. 2:12-CV-00147RAJ, 2012 WL 5290158 (W.D. Wash. September 18, 2012). While Spry Fox is deserving of its own analysis, in the interest omitting cumulative subject matter the authors leave that case for another day. Nonetheless, if Tetris Holding is of interest to you, Spry Fox will be as well.

77499 U.S. 340 (1991).

78 Ibid at 348 .

79 Ibid.

80 Ibid at 362 . 

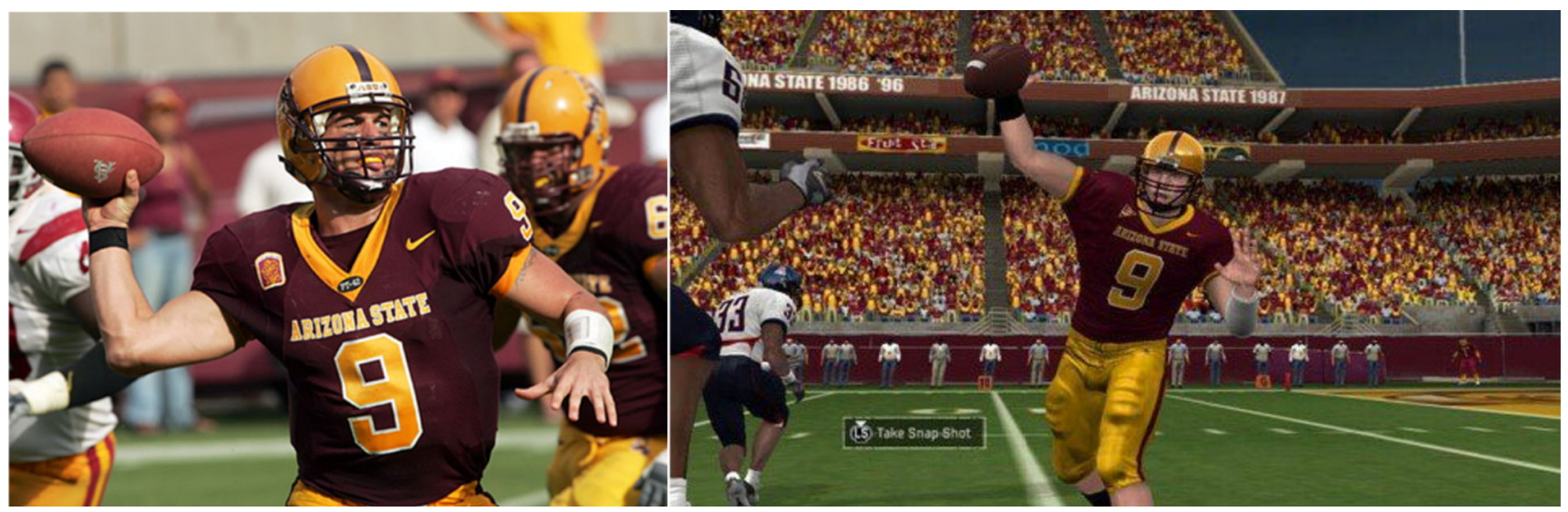

Figure 8 Hart v. Electronic Arts and In re NCAA - Remember to Pay Your Players

game devices would be eligible for copyright if it features an original selection or arrangement of standard game devices. Nonetheless, the copyright would be limited to the particular selection or arrangement of standard game devices, and in no event may copyright extend to the standard game devices themselves. It is only a matter of time before a court so holds.

\section{Hart and Keller: rights of publicity in video games}

Despite the now ubiquitous consensus that video games are expressive works, the cases of two college football players, Ryan Hart and Samuel Keller, make clear that the use of likenesses may not be a 'new expression' so as to be excused from a right-of-publicity suit as a 'transformative work' ${ }^{81}$

Ryan Hart was a successful quarterback for Rutgers University from 2002 to 2005 , during which time he took his team to their first bowl game since $1978 .^{82}$ Hart was number 13 , was $6^{\prime} 2^{\prime \prime}$ tall, and weighed 197 pounds. ${ }^{83}$ In its NCAA Football game, Electronic Arts (EA) created a nameless quarterback for Rutgers who matched those exact specifications. ${ }^{84}$ College football players, who are considered amateur athletes, do not receive any direct compensation for the use of their likenesses (and, in fact, can be banned from play if they do so) ${ }^{85}$ Hart filed a lawsuit for violation of his right of publicity ${ }^{86}$ based on his claim that EA used his likeness without permission. ${ }^{87}$ EA argued that, irrespective of whether they violated Hart's rights and misappropriated his identity for commercial exploitation, the First Amended shielded EA from liability. ${ }^{88}$

The Third Circuit Court of Appeals considered a number of balancing tests, and eventually applied the transformative use test. ${ }^{89}$ Under the transformative use test, the court analyzed whether Hart's identity - made up of not only his likeness, but also biographical information - was 'sufficiently transformed' in the game. ${ }^{90}$ In order to achieve that transformation, a creator must make "something recognizably "his own", in order to qualify for legal protection [from a claim for infringement of one's right of publicity]' ${ }^{91}$

The court noted that the avatar resembled the real Hart in his hair color, body type, hair style, skin tone, and even in the choice of accessories he wore. ${ }^{92}$ The court was persuaded by the fact that NCAA Football's purpose was to 'create a realistic depiction of college football for the users', including a 'realistic representation of the players', and the mere fact that users could alter the avatar's appearance 'counts for little where the appeal of the game lies in users' ability to play "as, or alongside" their preferred players or team'. ${ }^{93}$ Rather, the court held that 'that realistic depictions of the players are the "sum and substance" of these digital facsimiles', rendering the use non-transformative. ${ }^{94}$

Similarly, Sam Keller was a starting quarterback for Arizona State and Nebraska, and also filed suit under
81 Hart v. Electronic Arts, Inc., 717 F.3d 141 (3rd Cir. 2013)

82 Ibid at $145-46$

83 Ibid.

84 Ibid.

85 Ibid at 145 .

86 Ibid at 146-47; see generally Zacchini v. Scripps - Howard Broad. Co., 433 U.S. 562, 574-75 (1977) (discussing the right of publicity).

87 Hart v. Electronic Arts, Inc., 717 F.3d 141, 146-47 (3rd Cir. 2013).

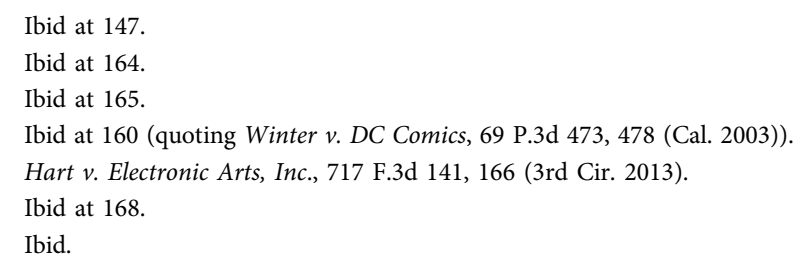


similar rationale. ${ }^{95}$ The Ninth Circuit focused predominantly on No Doubt v. Activision Publishing ${ }^{96}$ to establish that EA's use of Keller's (and the other class members') likeness was not a transformative use. 'Keller is represented as "what he was: the starting quarterback for Arizona State" and Nebraska, and "the game's setting is identical to where the public found [Keller] during his collegiate career: on the football field"'. ${ }^{97}$ Regarding the ability to alter avatars, the court agreed with the Third Circuit that 'these changes do not render the NCAA Football games sufficiently transformative to defeat a right-of-publicity claim'. ${ }^{98}$

In creating a video game world, a content creator often needs to fill out that world with realistic trappings in order to create a believable world. When it comes to trademarks, the desire to make that world as believable as possible often works in the video game developer's favor, based on the Rogers v. Grimald $i^{99}$ test, to avoid an allegation of infringement. ${ }^{100}$ However, the same desire to create as realistic a world as possible has the opposite intended effect when it comes to one's right of publicity. Unlike in cinema where an actor has to be physically present to be filmed, the nature of game design means that one does not need to have any contact with an individual to create a digital model and add an avatar of that individual to one's game. In this context, it is important for content creators to remember that they must acquire the right to use an identifiable likeness just as they would any other intellectual property asset.

\section{The WoW Glider case: cheaters never win}

As video game development becomes increasingly lucrative as a business, the business of would-be infringers has boomed along with it. As they say, where there is money, litigation will follow. The Digital Millennium Copyright Act ('DMCA'), was enacted in 1998 to conform the United States to its obligations under certain World Intellectual Property Organization treaties signed as a result of increasing and more financially detrimental copyright infringement. ${ }^{101}$ The DMCA protects against a potential infringer who

95 In re NCAA Student-Athlete Name \& Likeness Licensing Litig., 724 F.3d 1268, 1271-72 (9th Cir. 2013).

96192 Cal. App. 4th 1018 (Ct. App. Cal. 2011).

97 In re NCAA Student-Athlete Name \& Likeness Licensing Litig., 724 F.3d at 1276 (quoting Keller v. Elec. Arts, Inc., No. C 09-1967 CW, 2010 WL 530108 , at ${ }^{*} 5$ (N.D. Cal. February 8,2010$)$ ).

98 In re NCAA Student-Athlete Name \& Likeness Licensing Litig., 724 F.3d at 1278.

99875 F.2d 994 (2nd Cir. 1989).

100 See Rogers, 875 F.2d at 999. See also Brown v. Electronic Arts, Inc. 724 F.3d 1235, 1244 (9th Cir. 2013) (holding Jim Brown's likeness was artistically
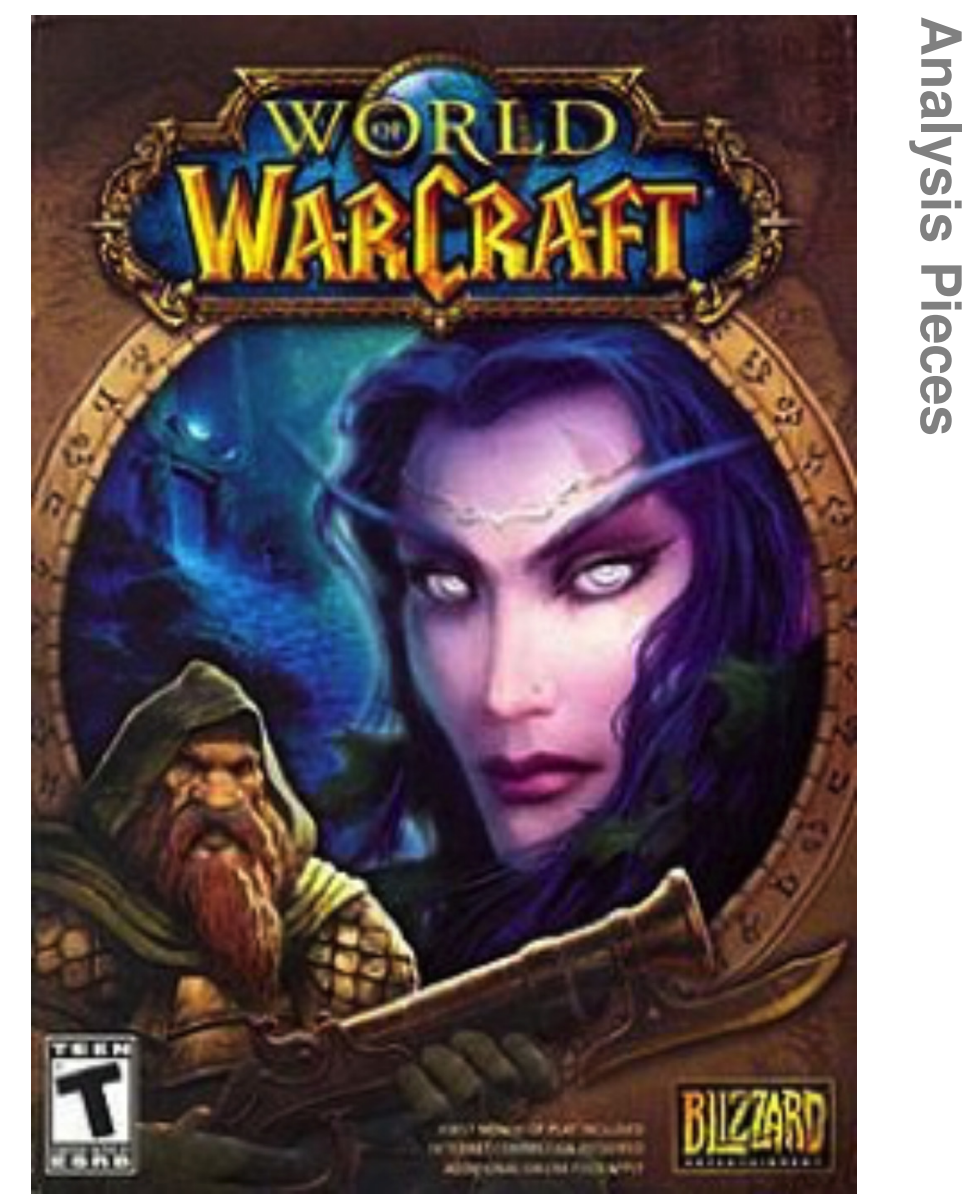

Figure 9 MDY v. Blizzard - The DMCA Enters the Game

(1) traffics in (2) a technology or part thereof (3) that is primarily designed, produced, or marketed for, or has limited commercially significant use other than (4) circumventing a technological measure (5) that effectively controls access (6) to a copyrighted work'. ${ }^{102}$

Blizzard released its exceedingly popular World of Warcraft ('WoW') game in 2004. ${ }^{103}$ WoW is enjoyed by players across the world who subscribe and $\log$ in to play online; there are no single-player or offline modes. ${ }^{104}$ Players advance by killing monsters, raiding dungeons, and battling other teams of players, all for the purpose of earning more in-game currency or better

relevant to Madden NFL because the game attempts to provide a realistic simulation of the sport); E.S.S. Entm't 2000, Inc. v. Rock Star Videos, Inc. 547 F.3d 1095, 1100 (9th Cir. 2008) (holding the strip club was artistically relevant to the game's portrayal of Los Angeles).

101 MDY Indus., LLC v. Blizzard Entm't, Inc., 629 F.3d 928, 942 (9th Cir 2010), as amended on denial of reh'g (February 17, 2011), opinion amended and superseded on denial of reh'g, No. 09-15932, 2011 WL 538748 (9th Cir. February 17, 2011); see also 17 U.S.C. $\$ 1201$.

$102 M D Y, 629$ F.3d at 953; see also 17 U.S.C. $\$ 1201(\mathrm{a})(2)$.

103 Ibid at 935.

104 Ibid. 
weapons and armor. ${ }^{105}$ This process of completing quests and engaging in battle can be at times tedious, and the process of leveling up your character is aptly referred to as 'grinding. ${ }^{106}$

MDY programmed an automatic software robot ('bot') that could automatically play the early levels of the game so that players did not have to sit and 'grind' in order to advance their character. ${ }^{107}$ The bot did it automatically. To combat this, Blizzard instituted a technology called Warden, which prevents unauthorized third-party software - including bots - from connecting to WoW's servers. ${ }^{108}$ MDY then created software (for an additional monthly fee to MDY's users) to hide these bots from Warden. ${ }^{109}$ In three years, MDY made US $\$ 3.5$ million in subscription fees. ${ }^{110}$ Because Warden did not affect access to the WoW's files and resources (which are readily accessible on a user's hard drive), the Ninth Circuit held that MDY did not infringe Blizzard's copyrights in the literal elements of $W o W .^{111}$

However, the court held that MDY did violate Blizzard's rights regarding dynamic, non-literal elements of the game. ${ }^{12}$ The court, in a first, expressly held that the audiovisual experience of the game constituted a protected work under the Copyright Act. ${ }^{113}$ Blizzard's Warden restricts access to that experience by scanning the computer's RAM and looking for software such as Glider. ${ }^{114}$ Therefore, even though the user has access to the game's data files regardless of Warden, the user does not have access to the dynamic game experience that makes use of those files unless Warden grants them access. ${ }^{115}$

The MDY decision marks a significant departure from early case law that strictly limited copyright infringement to a game's literal elements, and that did not grant any protection to a game's functionality without a patent. ${ }^{116} \mathrm{MDY}$ ventured from this path in two respects. First, the court stated that the dynamic-nonliteral elements of WoW were copyrightable. ${ }^{17}$ Those aspects inherently include at least some functionality.

105 Ibid.

106 See generally Neil Sorens, Rethinking the MMO, Gamasutra (March 26, 2007), www.gamasutra.com/view/feature/1583/rethinking_the_mmo.php? page $=3$ (defining the term Grinding).

107 Ibid at $935-36$.

108 Ibid at 936.

109 Ibid.

110 Ibid.

111 Ibid at 952; cf. Sony Computer Entm't Am., Inc. v. Filipiak, 406 F.Supp.2d 1068 (N.D. Cal. 2005).

112 MDY, 629 F.3d at 953.

113 Ibid at 953-54. While the Supreme Court made a similar holding in Brown v. Entertainment Merchants Ass'n, the MDY case predates that case.

114 Ibid at 954 .

115 Ibid.

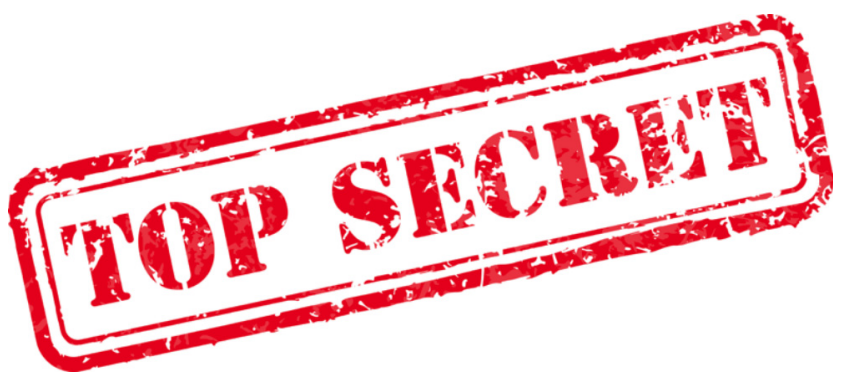

Figure 10 Oculus v. ZeniMax - Don't Try to Be Luckey With Your Contracts

Second, the DMCA protects any copyright behind a sufficient technological measure, including any functionality therein. ${ }^{118}$ Because the game itself is protectable expression under copyright law, any functionality that is circumvented by Glider was protected under the DMCA, regardless of its status of copyright protection. ${ }^{119}$ Thus, indirectly, the DMCA allows for copyright law to protect at least some functional aspects of a video game as well as its creative expression, which has been the subject of some criticism of the DMCA in the past. ${ }^{120}$

\section{Oculus v. ZeniMax: a rift in trade secrets}

An oft-overlooked form of IP protection is trade secrets, for which the U.S. recently passed its first federal trade secret law. ${ }^{121}$ As content creators search for new ways to protect their innovations, and with video games advancing in complexity and bleeding into hardware, often the most valuable intellectual property involves trade secret techniques and the industry experience of a company's employees.

In March of 2012, ZeniMax (owner of Bethesda Softworks and id Software, among others) had developed a prototype virtual reality ('VR') headset that overcame existing hurdles in the industry, particularly the latency

116 See, e.g. Incredible Techs, Inc. v. Virtual Techs, Inc., 400 F.3d 1007, 101215 (7th Cir. 2005); Atari, Inc. v. N. Am. Philips Consumer Elecs. Corp., 672 F.2d 607, 615 (7th Cir. 1982); Tetris Holding, LLC v. Xio Interactive, Inc., 863 F.Supp.2d 394, 403-04 (D.N.J. 2012); see also Atari Games Corp. v. Oman, 979 F.2d 242, 245 (D.C. Cir. 1992) ('The hallmark of a video game is the expression found in "the entire effect of the game as it appears and sounds", its "sequence of images"') (quoting Stern Elecs., Inc. v. Kaufman, 669 F.2d 852, 857 (2nd Cir. 1982).

117 MDY, 629 F.3d at $953-54$.

11817 U.S.C. $\$ 1201$.

119 MDY, 629 F.3d at 952-54.

120 See Murphy v. Millennium Radio Group LLC, 650 F.3d 295, 300 (3rd Cir. 2011) ('The DMCA has been criticized in some circles for its "potentially overbroad scope ... and its ability to chill legitimate and, in some cases, constitutionally protected speech") (quoting Gideon Parchomovsky; Philip J. Weiser, 'Beyond Fair Use', (2010) 96 Cornell L. Rev. 91, 104).

12118 U.S.C. $\$ 1839$. The Defend Trade Secrets Act of 2016 ('DTSA'). 
between a user moving his or her head and the VR display updating based on its orientation. ${ }^{122}$ After learning of Palmer Luckey's Rift headset on the Internet, John Carmack, himself a ZeniMax employee, obtained a prototype and turned it into a powerful device by incorporating Zenimax's own technology into the Rift. ${ }^{123}$ In order to protect its investment, ZeniMax entered into a non-disclosure agreement ('NDA') with Luckey that said, in part, '[a]ll Proprietary Information . . . which shall come into [Luckey's] custody or possession, is and at all times shall be the exclusive property of [ZeniMax]'. ${ }^{124}$

This arrangement began to break down fairly quickly. ZeniMax ('for unknown reasons') continued to provide proprietary information to Luckey and his new company, Oculus, for several months. ${ }^{125}$ However, Luckey demonstrated the device at the E3 conference using DOOM 3 (a ZeniMax title Oculus was prohibited from using), and Oculus repeatedly refused to compensate ZeniMax for the proprietary technology that was now incorporated into the Rift. ${ }^{126}$ Further, Oculus hired Carmack as its Chief Technology Officer when his employment contract with ZeniMax expired, along with five additional senior ZeniMax employees. ${ }^{127}$ Facebook later bought Oculus for US\$2 billion in cash and stock within a year, despite knowing that the intellectual property underlying the Rift VR headset was under dispute. ${ }^{128}$

Following suit, a jury awarded substantial damages to ZeniMax, despite the jury finding Oculus innocent of misappropriating trade secrets. ${ }^{129}$ Oculus was required to pay ZeniMax US\$200 million for violating the NDA, and US\$50 million for copyright infringement. ${ }^{130}$ Oculus and Palmer Luckey were each required to pay ZeniMax US\$50 million, and Oculus CEO Brendan Iribe ordered to pay ZeniMax US\$150 million, for false designation of origin (i.e. publicly misrepresenting the origin story of the Oculus Rift device). ${ }^{131}$ However, U.S. District Judge Ed Kinkeade reduced the damages to US\$250 million and eliminated the damages attributed to Brendan Iribe and Palmer Luckey. ${ }^{132}$

As the gaming market continues to expand and grow, it is likely that companies will continue to place a continued emphasis on their most valued asset: people. Companies

\footnotetext{
122 ZeniMax Media, Inc. v. Oculus VR, LLC, 166 F.Supp.3d 697, 700 (N.D Tex. 2015).

123 Ibid at $700-01$.

124 Ibid at 701 .

125 Ibid at 702 .

126 Ibid at 702 .

127 Ibid.

128 Ibid.

129 Reading of the Verdict, Zenimax Media Inc. v. Oculus VR, LLC, 2017 WL 3493903 (N.D. Tex. January 26, 2017) (No. 3:14-CV-1849-K).
}

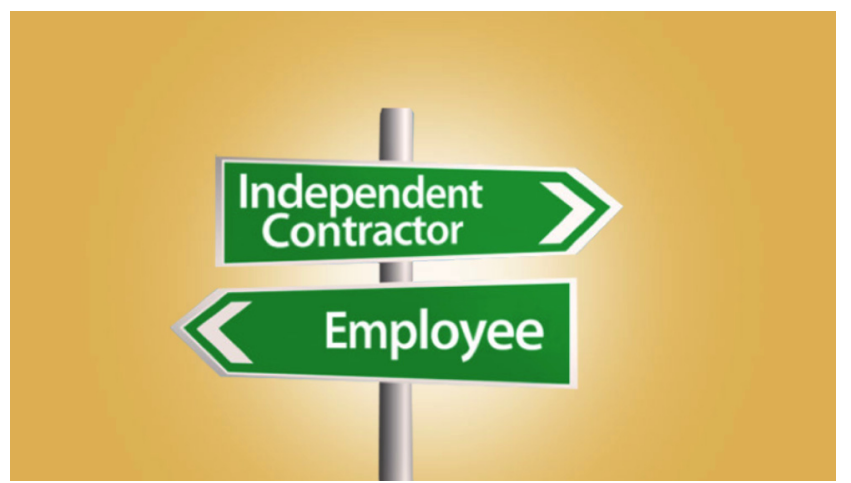

Figure 11 GameDevCo. v. Independent Contractor - The Case That Never Goes to Trial

have invested considerable resources in acquiring and training talent to create games, and go to great lengths to protect the resulting IP. It is only logical that trade secret cases will become more prevalent in the future. Companies should therefore take appropriate steps not only to ensure that their own trade secrets are well guarded, but also to ensure that new employees do not unscrupulously bring another company's trade secrets along with them.

\section{Independent Contractors: the case that's never litigated}

There's one case that never goes to trial, and never will, so we would be remiss not to mention it. Under U.S. law, the default rule of copyright ownership is that the author of a copyrighted work is the original owner of the work, unless the work is a work made for hire. ${ }^{133}$ Under U.S. law a work is a work made for hire if: 1) the work is made by an employee in the ordinary course of employee, OR 2) the parties - A) agree in writing that the work is a work made for hire, AND B) the work falls into one of nine statutorily defined categories of works. ${ }^{134}$

There are two potential pitfalls here. First, and foremost, if a developer does not have a written contract with its independent contractors, then those independent contractors likely own the copyright in the source code they create, whereas the developer at best has an implied license to the source code for the immediate

\footnotetext{
130 Ibid.

131 Ibid.

132 ZeniMax Media Inc. v. Oculus VR LLC, No. 3:14-CV-1849-K, 2018 WL 3135915 (N.D. Tex. June 27, 2018). See also Stefanie Fogel, 'Judge Halves $\$ 500$ Million Payout In Facebook ZeniMax Lawsuit', Forbes (June 28, 2018), https://variety.com/2018/gaming/news/zenimax-facebook-lawsuitaward-halved-1202860452/. ZeniMax is appealing the District Judge's decision to reduce the damages awarded by the jury.

13317 U.S.C. $\$ 201$.

13417 U.S.C. $\$ 101$.
} 
project in which its being used. However, if the game is successful and the developer wants to reuse the source code in a second version of the game, the developer might be faced with having to negotiate with the independent contractor for rights to use the software again in version 2.0. Failure to secure such rights has forced game companies to pay settlements into the multi-millions of dollars just to reuse software they thought they already owned. ${ }^{135}$ This situation could easily have been avoided by ensuring there was a clear written contract with the independent contractor up front.

Second, through a quirk of U.S. copyright law, the nine statutory categories of works subject to being made works for hire through contract does not include literary works. ${ }^{136}$ Source code is considered a literary work under U.S. law. ${ }^{137}$ Therefore, it might not be enough even when a developer has a contract with an independent contractor and refers in the contract to the software as a work for hire. Rather, the contract should include both a work for hire provision as well as an assignment clause where the independent contractor assigns his or her rights to the game developer. It is worth noting that one of the nine statutory categories of works included is audiovisual works and contributions to audiovisual works, which includes video games. ${ }^{138}$ So even if the assignment clause is omitted, the contractual work for hire provision might still apply in the context of a video game. However, this is still untested under U.S. law. ${ }^{139}$ Regardless, it advisable to always have a contract including both work for hire and assignment clauses with all independent contractors.

\section{Conclusion}

As the above cases evidence, video game law, and courts themselves, have indeed leveled up. Historic cases - which, in terms of video games, means only about 40 years ago - granted lesser protection to video games, resulting in more broadly permitted copying. That tide has now shifted. Cases like Tetris Holding v. Xio and MDY Donnely show that US courts are willing to grant significant and increasingly broader intellectual property protections to games. Whereas video games were once in legal purgatory - being granted little meaningful protection by copyrights and patents alike - thanks to Brown v. EMA video games now enjoy the strongest of copyright protection on par with books, plays and movies. ${ }^{140}$

While games are clearly expression, and are protected under the First Amendment, this expression can still be limited by the rights of others, as we saw in the NCAA and Right of Publicity cases. ${ }^{141}$ In addition, it's important to keep in mind that all games are the product of the people and companies that make them, and cases such as ZeniMax are likely to become more common in the future. ${ }^{142}$

The games industry is the soon-to-be most profitable sector in entertainment, ${ }^{143}$ so it is only natural that courts grind away and level up alongside it. Indeed, courts have come a long way towards providing video game copyright holders with the protection they deserve (despite the occasional misstep such as the well-intentioned Micro Star case). However, just when you think you have reached the final castle, found the princess, and it is game over, along comes augmented and virtual reality and a whole plethora of new issues they present. We will most certainly have to invest countless hours of 'research' - legal or otherwise - to ensure that we stay abreast of these cutting edge technologies and the legal issues they raise. Indeed, as video game lawyers, we have the best jobs in the legal profession. Game on!
135 See e.g. Antonick v. Elec. Arts, Inc., 841 F.3d 1062 (9th Cir. 2016) (lawsuit seeking contract damages for unpaid royalties regarding derivative works in Madden games).

13617 U.S.C. $\$ 101$. The nine categories include 'a work specially ordered or commissioned for use as a contribution to a collective work, as a part of a motion picture or other audiovisual work, as a translation, as a supplementary work, as a compilation, as an instructional text, as a test, as answer material for a test, or as an atlas'.

137 See e.g. Oracle Am., Inc. v. Google Inc., 750 F.3d 1339, 1355 (Fed. Cir 2014) ('It is well established that copyright protection can extend to both literal and non-literal elements of a computer program. The literal elements of a computer program are the source and object code') (citation omitted).

13817 U.S.C. $\$ 101$. See also Copyright Office Circular 61: Copyright Registration of Computer Programs at 6 ('A videogame typically contains two major components: audiovisual material that appears on screen and the computer program that runs the game').

139 In Antonick v. Electronic Arts, Mr. Antonick was hired as an independent contractor, and received royalties on derivative works as well as the originally created work, 841 F.3d 1062, 1064-65 (9th Cir. 2016). However, ownership of Mr. Antonick's creations was never in dispute, so the court never reached the issue of whether his video game contributions were works for hire. Ibid.

140 Patent law has increased its protection of video games as well, but that is beyond the scope of this note. See, e.g. Dannenberg et al., The Patent Arcade legal blog, accessible at www.PatentArcade.com (database of US video game patents).

141 See In re NCAA Student-Athlete Name \& Likeness Licensing Litig., 724 F.3d 1268 (9th Cir. 2013); Hart v. Electronic Arts, Inc., 717 F.3d 141 (3rd Cir. 2013).

142 See ZeniMax Media, Inc. v. Oculus VR, LLC, 166 F.Supp.3d 697, 700 (N.D Tex. 2015). See e.g. Waymo LLC v. Uber Techs, Inc., 870 F.3d 1350 (Fed. Cir. 2017) (Waymo sued Uber after a Waymo employee joined Uber and allegedly took thousands of documents related to self-driving car technology).

143 See Trevir Nath, 'Investing in Video Games: This Industry Pulls In More Revenue Than Movies, Music', NASDAQ (June 13, 2016), https://www. nasdaq.com/article/investing-in-video-games-this-industry-pulls-inmore-revenue-than-movies-music-cm634585. 